\title{
REKREASI SEBAGAI PUSAT REHABILITASI GEN Z
}

\author{
Grace Jovita $^{1)}$, Dewi Ratnaningrum ${ }^{2)}$ Maria Veronica Gandha ${ }^{3)}$ \\ 1)Program Studi S1 Arsitektur, Fakultas Teknik, Universitas Tarumanagara, gracejovita16@gmail.com \\ 2) Program Studi S1 Arsitektur, Fakultas Teknik, Universitas Tarumanagara, dewir@ft.untar.ac.id \\ 3) Program Studi S1 Arsitektur, Fakultas Teknik, Universitas Tarumanagara, mariag@ft.untar.ac.id
}

\begin{abstract}
Abstrak
Generasi Z memiliki pengaruh yang signifikan terhadap perkembangan teknologi, produktivitas, dan interaksi sosial. Dalam fenomena Covid - 19 yang terjadi di tahun 2020 ini menyebabkan manusia sadar akan seberapa pentingnya interaksi sosial tatap muka. Oleh karena itu, penyediaan fasilitas sosial yang dapat mengembalikan interaksi sosial antar manusia sangat dibutuhkan. Tujuan penelitian ini diantaranya adalah untuk mengembalikan interaksi sosial antar manusia terutama pada Generasi Z pasca pandemi, memberikan rehabilitasi ruang melalui ruang sosial berupa hiburan secara bertahap, menghadirkan fasilitas yang mampu memenuhi kebutuhan sosial masyarakat, dan menciptakan program kegiatan yang mampu memenuhi kebutuhan sosialisasi masyarakat sekaligus meningkatkan kualitas hidup masyarakat setempat. Dilansir Maslow Hierarchy of Needs ada lima tahap kebutuhan manusia yaitu aktualisasi diri, menghargai, kasih sayang, keamanan, dan kebutuhan psikologis. Yang dimana Generasi Z sangat dibutuhkan dalam memenuhi kebutuhan. Oleh karena itu diperlukan hunian yang memerlukan konsep teknologi yang dapat digunakan lebih efektif dalam berinteraksi secara lebih baik dibanding dengan tatap muka secara langsung. Metode yang digunakan adalah dengan pendekatan komunikasi yang digunakan melalui pengamatan dan pengumpulan data dari internet serta korelasi untuk mencari hubungan antara dua variabel yang bersifat kuantitatif. Hasil yang didapatkan adalah dengan membuat public space dimana para Generasi $Z$ dapat memanfaatkan teknologi serta arsitektur yang mendukung dalam proses interaksi.
\end{abstract}

Kata kunci: Pemulihan; Rehabilitasi; Hiburan; Fundamental.

\begin{abstract}
Generation $Z$ has a significant influence on technological developments, productivity, and social interactions. In the Covid-19 phenomenon that occurred in 2020, it caused humans to become aware of the importance of face-to-face social interactions. Therefore, the provision of social facilities that can restore social interaction between humans is needed. The purpose of this research is to restore socialization between people, especially in the $z$ generation after the pandemic, to provide spatial rehabilitation through social space in the form of entertainment in stages, to provide facilities that are able to meet the social needs of the community, and to create activity programs that are able to meet the socialization needs of the community while improving the quality of life local community. Reported by Maslow's Hierarchy of Needs, there are five stages of human needs, namely selfactualization, respect, compassion, security, and psychological needs. Which is where generation $Z$ is needed to make ends meet. Therefore, it is necessary to have housing that requires a technology concept that can be used more effectively in interacting better than face-to-face. The method used is a communication approach which is used through observation and data collection from the internet and correlation to find a relationship between two quantitative variables. The results obtained are to create a public space where generation z can take advantage of technology and architecture that support the interaction process.
\end{abstract}

Keywords: Recovery; Rehabilitation; Entertainment; Fundamental. 


\section{PENDAHULUAN}

\section{Latar Belakang}

Fenomena COVID - 19 ini menyebabkan manusia sadar akan seberapa pentingnya interaksi sosial tatap muka. Hal-hal ini terjadi di kota-kota besar seperti Jakarta, menimbulkan dampak negatif pada mental health masyarakat. Berdasarkan penelitian WHO mengenai mental health issue jika hal ini dibiarkan berdampak buruk, seperti depresi yang dapat disebabkan kurangnya interaksi sosial sebagai salah satu kebutuhan dasar mereka.

Dilansir berita LIPUTAN 6 tanggal 31 Maret 2017, Dalam 20 tahun ke depan 80\% interaksi manusia akan melalui media internet yang membuat semakin berkurangnya interaksi sosial tatap muka. Selain itu, kurangnya fasilitas publik yang dapat menimbulkan interaksi semakin berkurang. Fasilitas berupa entertainment yang dikenal sebagai tempat bersosialisasi perlahan hilang. Jakarta Selatan yang dikenal dengan area hiburannya terutama di Kemang menjadikan tempat yang cocok untuk proyek ini (https://www.liputan6.com/news/read/2904105/kemangtempat-jin-buang-anak-yang-menjelma-kawasan-elite). Oleh karena itu, penyediaan fasilitas sosial yang dapat mengembalikan interaksi sosial antar manusia sangat dibutuhkan. Langkanya arsitektur yang dapat menyediakan tempat untuk meningkatkan interaksi sosial terhadap issue ini, menyebabkan seberapa krusialnya pengembalian normalitas terhadap interaksi masyarakat.

\section{Rumusan Permasalahan}

Berdasarkan latar belakang tersebut, terdapat rumusan permasalahan yang terjadi antara lain:

- Terdapat isu kesehatan mental yang diakibatkan stress

- Mengembalikan pentingnya komunikasi antar manusia yang sudah memudar

- Memanfaatkan teknologi untuk mengembalikkan komunikasi antar manusia

\section{Tujuan}

- Mengembalikan sosialisasi antar manusia terutama pada Generasi Z pasca pandemi.

- Memberikan space rehabilitasi melalui social space berupa entertainment secara bertahap.

- Menghadirkan fasilitas yang mampu memenuhi kebutuhan sosial masyarakat

- Menciptakan program kegiatan yang mampu memenuhi kebutuhan sosialisasi masyarakat sekaligus meningkatkan kualitas hidup masyarakat setempat

\section{KAJIAN LITERATUR}

\section{Technology Effect on Culture}

Menurut Generasi Z telah lahir dalam teknologi baru - dari penggunaan media digital dan masalah kesehatan mental yang terkait dengan budaya teknologi kita yang mencakup penembakan massal dan kemauan yang lebih besar dari masyarakat untuk menerima kenyataan kematian. Berdasarkan data dari WHO kesehatan mental merupakan salah satu aspek terbesar penyebab kematian.

Salah satu masalah yang paling terabaikan saat ini, misalnya, adalah bagaimana Gen Z berupaya menghindari jebakan ekonomi di mana kaum Milenial terjebak, dari hutang pelajar yang sangat besar hingga pandangan yang bergeser tentang perlunya pendidikan tinggi. Faktanya, banyak Gen Z sudah menunjukkan keengganan yang tumbuh untuk mengambil hutang pinjaman siswa karena mereka lebih banyak berinvestasi dalam mengamankan kekayaan pribadi dan perencanaan keuangan daripada Milenial. Sebagai tambahan, Generasi Z lebih berinvestasi dalam menggunakan teknologi baru untuk memeriksa opsi ekonomi terbaik mulai dari mencari harga terbaik untuk produk sebelum membeli barang hingga penerapan teknologi dalam lebih banyak aspek kehidupan sehari-hari daripada generasi sebelumnya. 


\section{Technology and Mental Health}

Menurut Institut Kesehatan Mental Nasional, hampir satu dari lima orang dewasa mengalami penyakit mental pada tahun tertentu, dan antara empat hingga lima persen orang dewasa memiliki penyakit mental yang serius. Kira-kira satu dari lima remaja pernah atau akan mengalami gangguan mental pada suatu saat dalam hidup mereka. Pada saat yang sama, Dewan Nasional untuk Kesehatan Mental melaporkan bahwa hampir enam dari sepuluh (56\%) mencari layanan kesehatan mental baik untuk diri mereka sendiri atau untuk orang yang dicintai. Kondisi kesehatan mental yang dikombinasikan dengan kurangnya akses ke perawatan dan teknologi yang lebih canggih telah mendorong minat dalam penggunaan teknologi untuk meningkatkan dan memperluas perawatan kesehatan mental (https://www.bhjustice.org/technology-and-mental-health).

Teknologi dapat membantu dokter dalam menjangkau populasi yang sulit dijangkau karena hambatan geografis. Fakta bahwa beberapa jenis teknologi, seperti aplikasi, biayanya lebih rendah daripada perawatan tradisional dan juga dapat memfasilitasi akses. Kelebihan dengan adanya teknologi tersebut adalah kenyaman. Seperti yang ditunjukkan oleh National Institute of Mental Health, perawatan dapat dilakukan di mana saja dan kapan saja.

\section{Herman's Stages of Recovery}

Menurut pada buku karya Judith Herman (2002) ada tiga tahap yang menggambarkan secara terperinci proses penyembuhan yang terkait dengan pengalaman yang traumatis. Berikut adalah tahap - tahap penyembuhan menurut Judith Herman:

\section{a. Tahap Pertama}

Pada tahap pertama dalam menangani serta mengatasi masalah adalah dengan terapi atau konseling yang bermanfaat. Pada tahap pertama pemulihan dan pengobatan bukanlah tentang membahas ingatan tentang pengalaman yang tidak diinginkan. Tahap pertama merupakan kunci awal dalam sebuah pemulihan yang memfokuskan pada diri sendiri.

\section{b. Tahap Kedua}

Pada tahap kedua, tahap pemulihan di tahap ini disebut sebagai ingatan dan duka. Yaitu untuk merevisi arti kehidupan. Tujuannya adalah bahwa dengan metode yang efektif dan cepat menangani ingatan tanpa harus tersiksa dengan ingatan yang tidak mengenakkan.

\section{c. Tahap Ketiga}

Pada tahap ketiga dari pemulihan ini berfokus pada berhubungan kembali dengan orang-orang dan melakukan aktivitas yang bermakna pada hidup seseorang dan aspek-aspek lainnya.

\section{Stage of Mental Health}

Berdasarkan Dr. Jennie Byrne terdapat 7 fase dalam mental health

Tahap pertama - Pra-Konsepsi

Pada tahap ini orang yang mengalami gangguan akan menyadari bahwa ada sesuatu yang salah sehingga mengalami hal aneh dan terus terjadi tanpa mengambil tindakan lebih lanjut atau meminta pertolongan kepada ahli psikolog.

Tahap kedua - Kontemplasi

Pada tahap kedua, orang yang mengalami gangguan sudah mulai terganggu dan tidak mencari pertolongan dengan bantuan ahli karena takut akan terjadi sesuatu hal yang menyebabkan orang tersebut menjadi gila. 
Tahap ketiga - Krisis

Pada tahap ketiga dapat dihindari jika orang tersebut menyadari bahwa orang tersebut membutuhkan bantuan pada tahap kesatu dan dua. Namun jika orang tersebut tidak menyadari bahwa harus membutuhkan bantuan ahli maka akan mengalami rasa takut, khawatir ataupun kemarahan yang tidak dapat tertahankan.

Tahap keempat - Mencari Bantuan

Pada tahap ini, idealnya tahap ini terjadi pada tahap awal yang harus dilakukan jika mengalami gangguan. Namun seringkali sistem ini menjadi lambat pada tahap krisis. Oleh karena itu penderita harus dirawat secepat mungkin untuk membantu pasien yang mengalami gangguan.

Tahap kelima - Keterlibatan

Tahap ini merupakan tahap awal dalam masa perawatan. Kepercayaan merupakan tantangan yang akan dihadapi karena pasien akan mengeluarkan emosi dan mengekspresikannya dengan sangat menyakitkan. Oleh karena itu sangat penting untuk memulai proses pengembangan kepercayaan.

Tahap keenam - Pemulihan

Tahap pemilihan merupakan fase yang lama dimana orang tersebut ingin menemukan solusi dalam jangka panjang dalam menghadapi permasalahan. Dokter akan membantu untuk menemukan cara baru untuk memberdayakan diri dalam hidup yang lebih baik serta sehat.

Tahap ketujuh - Pemeliharaan

Kebanyakan orang mengabaikan tahap pemeliharaan. Dengan adanya pemeliharaan rutin krisis ataupun masalah tidak akan terlambat untuk menjalani proses perawatan yang lebih baik.

\section{The Continuum of the Levels of Development}

Penemuan ini dan pengerjaan semua sifat yang membentuk setiap jenis) pada awalnya dibuat oleh Don Riso pada tahun 1977, dan dikembangkan lebih lanjut oleh Don dengan Russ Hudson pada 1990-an.

Healthy

- Level 1: The Level of Liberation

- Level 2: The Level of Psychological Capacity

- Level 3: The Level of Social Value

Average

- Level 4: The Level of Imbalance/Social Role

- Level 5: The Level of Interpersonal Control

- Level 6: The Level of Overcompensation

Unhealthy

- Level 7: The Level of Violation

- Level 8: The Level of Obsession and Compulsion

- Level 9: The Level of Pathological Destructiveness

\section{METODE}

Metode Research

Dalam proses perancangan ini, terdapat beberapa metode yang digunakan: 
- Pendekatan komunikasi merupakan pendekatan yang digunakan melalui pengamatan dan pengumpulan data dari internet

- Korelasi, merupakan salah satu teknik analisis dalam statistik yang digunakan untuk mencari hubungan antara dua variabel yang bersifat kuantitatif

- Membentuk konsep serta program ruang dengan metode trans-programing berdasarkan kebutuhan dasar manusia menurut Abraham Maslow serta recovery of mental health menurut Herman MD

$\bullet$

\section{Metode Desain}

Seperti yang dikatakan Federico Babina 'it is quite true that architecture and the spaces that we live in influence our behaviour and psychopathology, who plans spaces, attitudes, behaviours and emotional experiences'. sebuah ruang dapat memberi efek pada perilaku, dalam merancang aspek psikologis juga diperhatikan. maka dari itu dengan mengimplementasi suasana psikologis dari tahapan pemulihan menurut MD Herman dan Dr. Bryne menjadi sebuah ilustrasi. Berikut ilustrasi dan tahapannya :

\section{Silence}

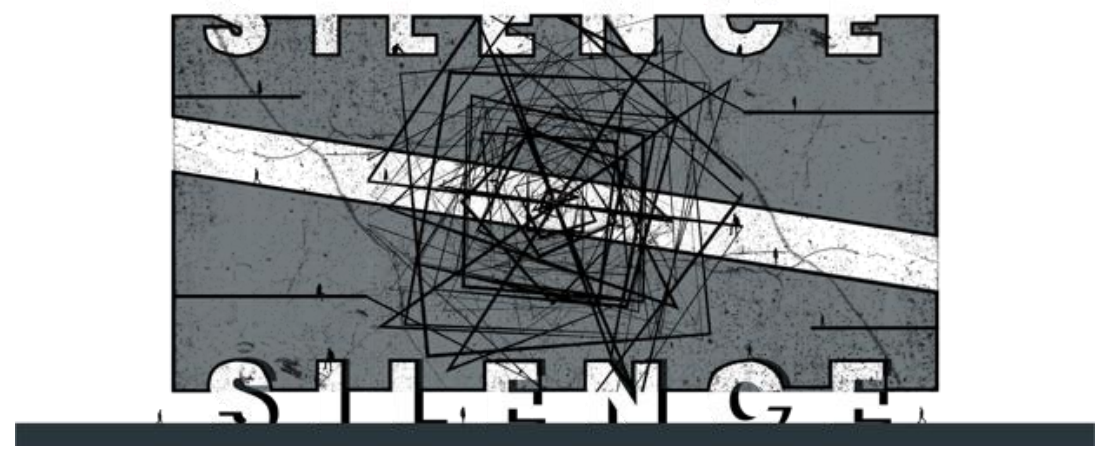

Gambar 1. Ilustrasi Silence

Sumber: Penulis, 2020

Merupakan tahap penerimaan dengan emosi yang dirasakan adalah holdback, mumet, trauma, pasrah, penolakan, dreamy.

Victimhood

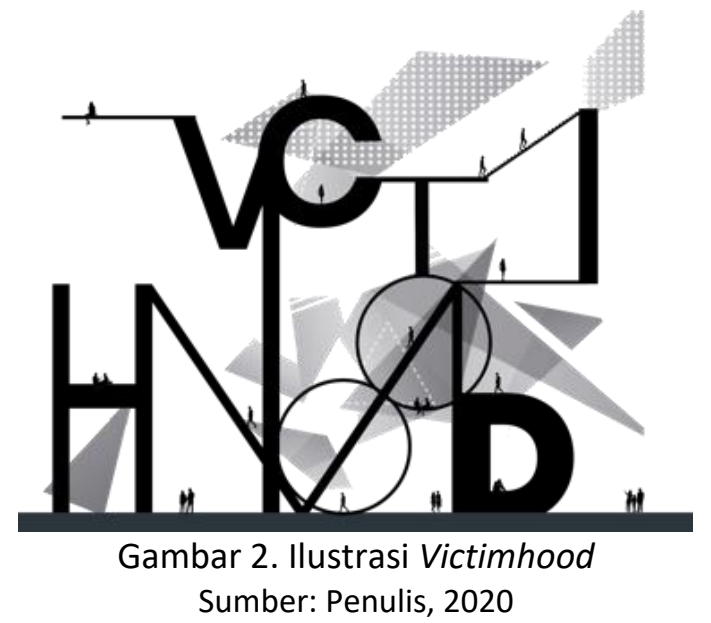

Sebagai tahap awal pemulihan dengan emosi yang dirasakan adalah kesadaran, kekhawatiran, keterbukaan, interaksi, paranoia. 


\section{Survivorhood}

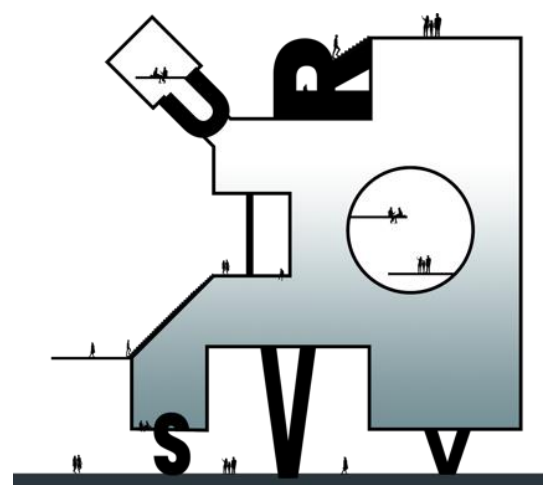

Gambar 3. Ilustrasi Survivor Hood Sumber: Penulis, 2020

Tahap ini merupakan tahap dimana dimulainya keterbukaan dan adaptasi. Merupakan tahap breakthrough dengan emosi yang dirasakan:

relief, acceptance, surviving.

\section{Thriving and Transcendence}

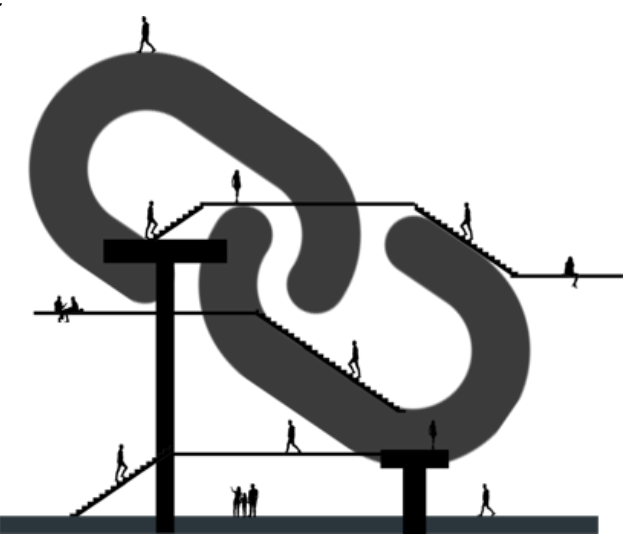

Gambar 4. Ilustrasi Thriving and Transcendence Sumber: Penulis, 2020

Pada tahap ini pengunjung sudah merasakan stabilitas dan mulai terkoneksi kembali dengan lingkungan, emosi yang dirasakan berupa:

connection, achievement, keterbukaan dan adaptasi.

\section{Reconnecting with Others}

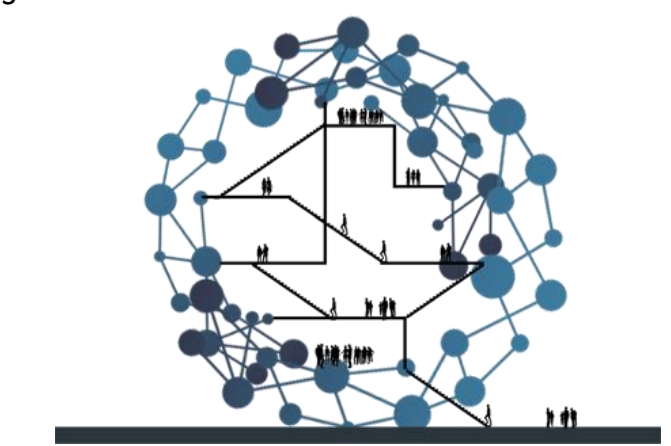

Gambar 5. Ilustrasi Reconnecting with Others

Sumber: Penulis, 2020

Tahap akhir dalam proses fase pengembalian, dimana pengunjung sudah merasakan kenormalan. Dengan adanya interaksi, kesenangan, kebebasan dan keterbukaan. 


\section{DISKUSI DAN HASIL}

Tapak

Tapak tersebut terletak di Jalan Bangka Raya secara eksisting tapak berupa perumahan, akan tetapi secara peruntukan berdasarkan peta LRK DKI Jakarta ini, merupakan zona oranye sebagai zona campuran.

Terdapat berbagai macam kegiatan berupa tempat berkumpul untuk anak muda, area komersial yang terdiri dari berbagai macam seperti restaurant dan area hiburan lainnya. terdapat pada second layer dari Jalan Kapten Tendean yang juga sebagai jalur utama daerah Kemang sendiri.

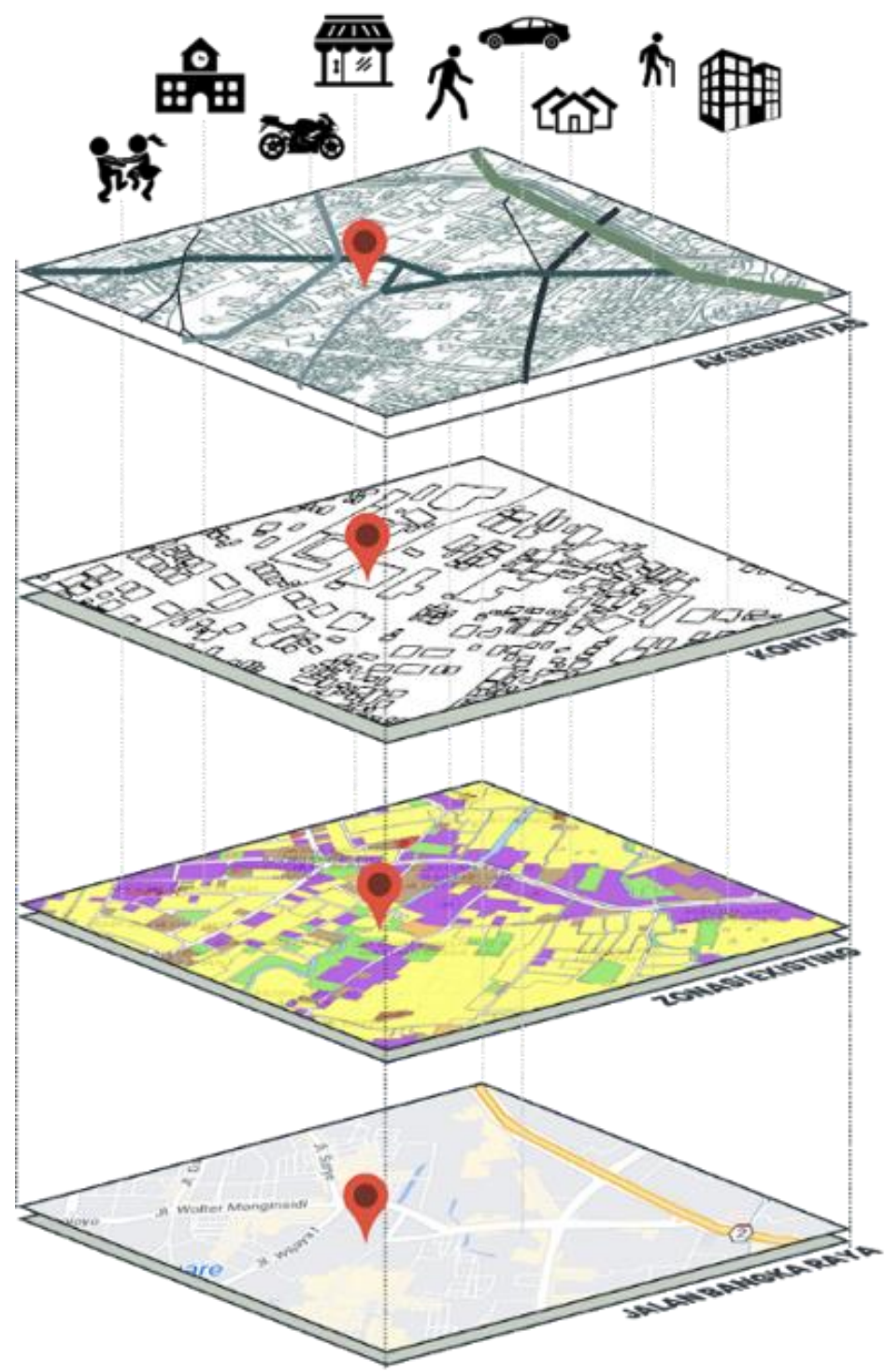

Gambar 6. Analisa Existing

Sumber: Penulis, 2020 


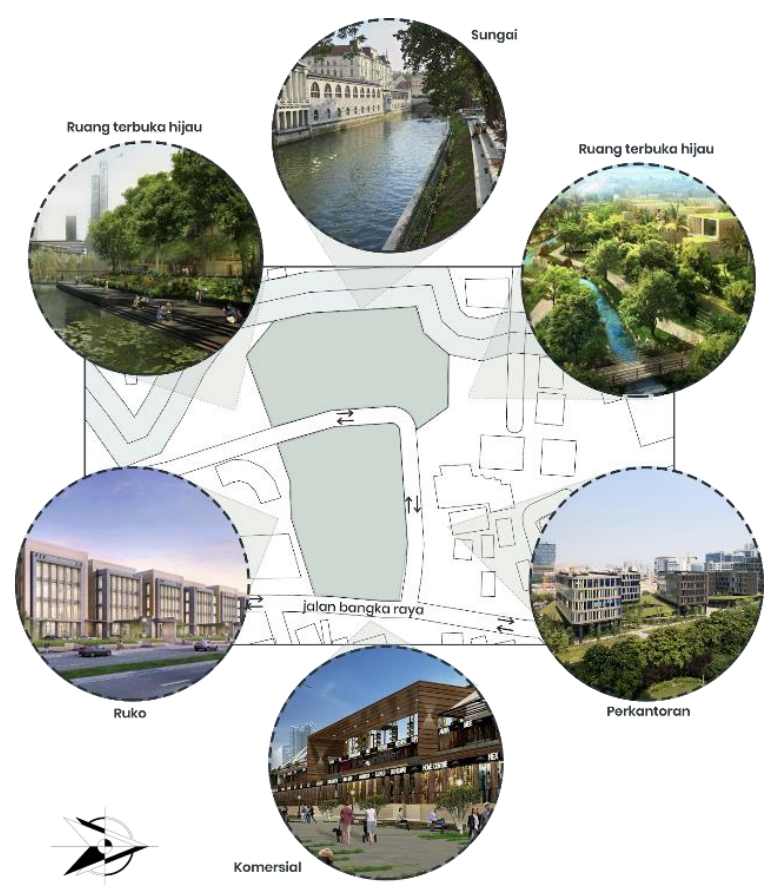

Kelurahan : Pela Mampang

Blok : 01

Sub Blok : 003

Zona : Zona Campuran

Sub Zona : C.1

ID Sub Blok : 01.003.C.1.f.2

KDB : 50

KLB : 2

$\mathrm{KB}: 4$

$\mathrm{KDH}: 35$

KTB : 50

Tipe : $\mathrm{T}$

Gambar 7. Tapak Eksisting

Sumber: Penulis, 2020
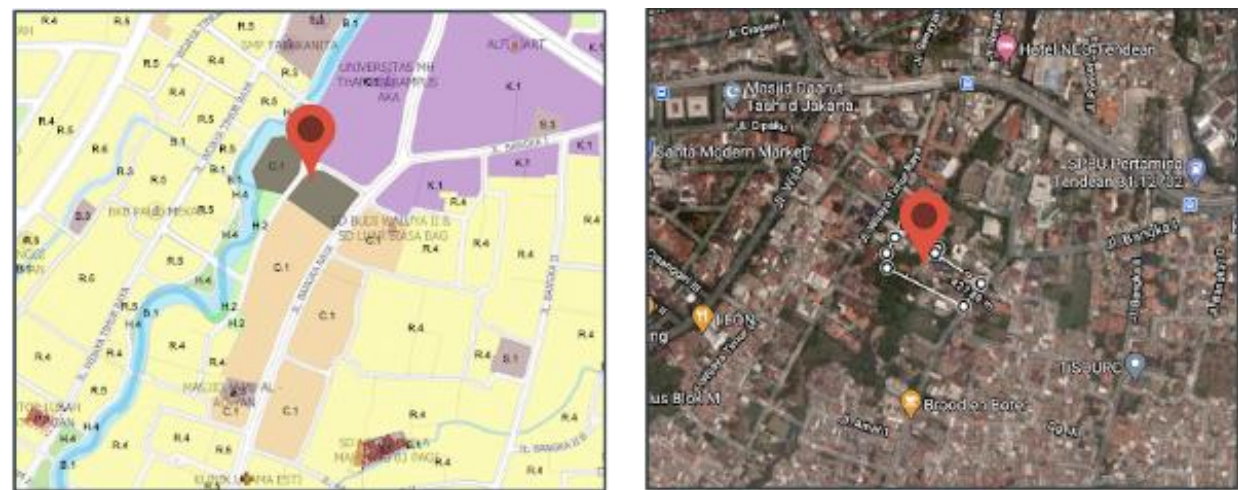

Gambar 8. Tapak Eksisting

Sumber: https://www.google.com/maps/@-6.2414855,106.816432,17.51z

\section{Gubahan Massa}

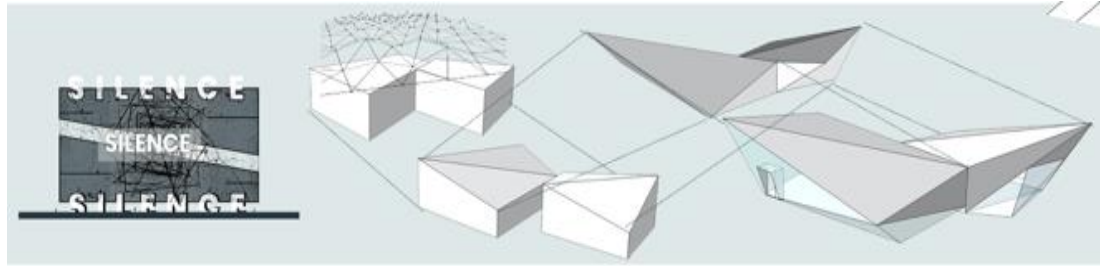

Gambar 9. Gubahan Massa 1

Sumber: Penulis, 2020

Bentuk masa pertama yang merupakan pintu masuk utama dan juga sebagai implementasi dari tahap pertama berupa silence. mengimplementasi ke bentuk fasad yang bersudut dari pengalaman hati yang dirasakan pada tahapan ini. 

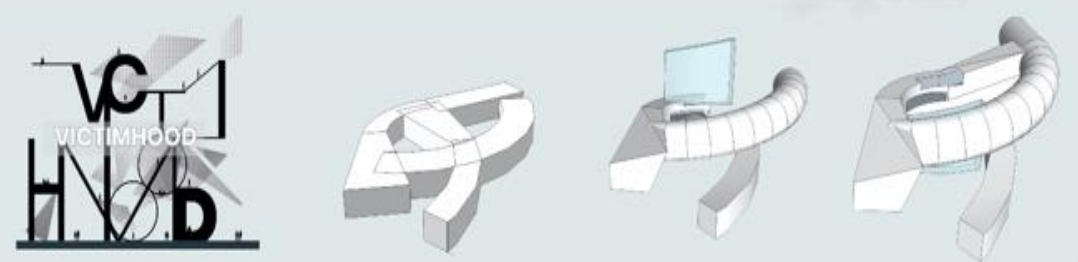

Gambar 10. Gubahan Massa 2

Sumber: Penulis, 2020

Merupakan bentuk yang mengimplementasi tahap victimhood dimana pada tahapan ini orang-orang memiliki kecenderungan untuk lanjut atau berputar balik. dengan suasana hati yang bergejolak tergambarkan pada sambungan-sambungan masa ini. pada tahapan ini menggambarkan keraguan serta keamanan secara bersamaan untuk memberikan sekepracaraan yang tergambarkan dari pengalaman ruang di tahap ini tergambarkan dengan bersatunya dengan alam.

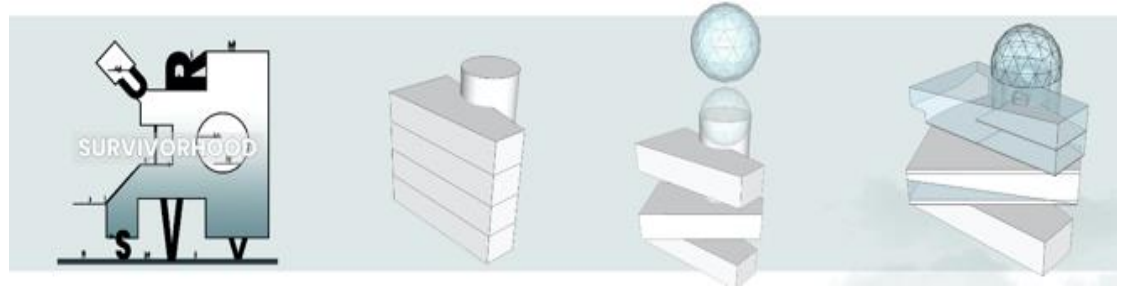

Gambar 11. Gubahan Massa 3

Sumber: Penulis, 2020

Tahapan ini menunjukkan kestabilan dan tergambarkan pada masa yang terletak di tengah tapak dengan puncak yang lebih tinggi dari 3 tahap pertama. memberikan stabilitas serta apresiasi terhadap mereka yang sudah berani melanjutkan tahapan pemulihan.

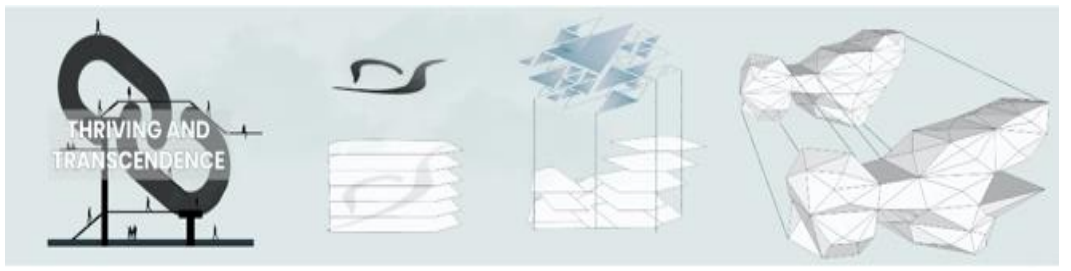

Gambar 12. Gubahan Massa 4

Sumber: Penulis, 2020

Mengimplementasi sebuah ilustrasi yang mendukung stabilitas dan maintenance dimana untuk mereka yang membutuhkan relaksasi maupun mereka yang butuh pengalihan. dipadu dengan bentukan terdiri dari potongan segitiga yang membentuk suatu yang lebih dinamis menggambarkan keadaan manusia. Menggambarkan keadaan mental manusia bagi mereka yang terlihat baik dan stabil dari sisi luar tetapi sebenarnya mereka menyatukan apapun itu yang terjadi dalam hidup menjadi diri mereka sebenarnya.
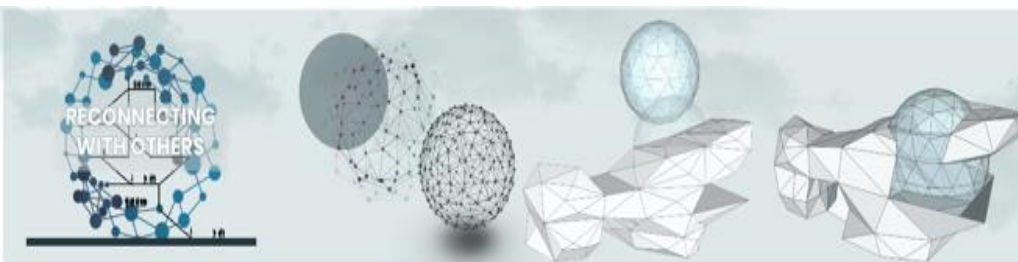

Gambar 13. Gubahan Massa 5

Sumber: Penulis, 2020 
Dengan menambahkan bola pada masa ini yang melambangkan kesatuan dengan program pada tahapan akhir. Menggambarkan suatu achievement mereka yang sudah berhasil dan berusaha untuk maintain stabilitas tersebut.

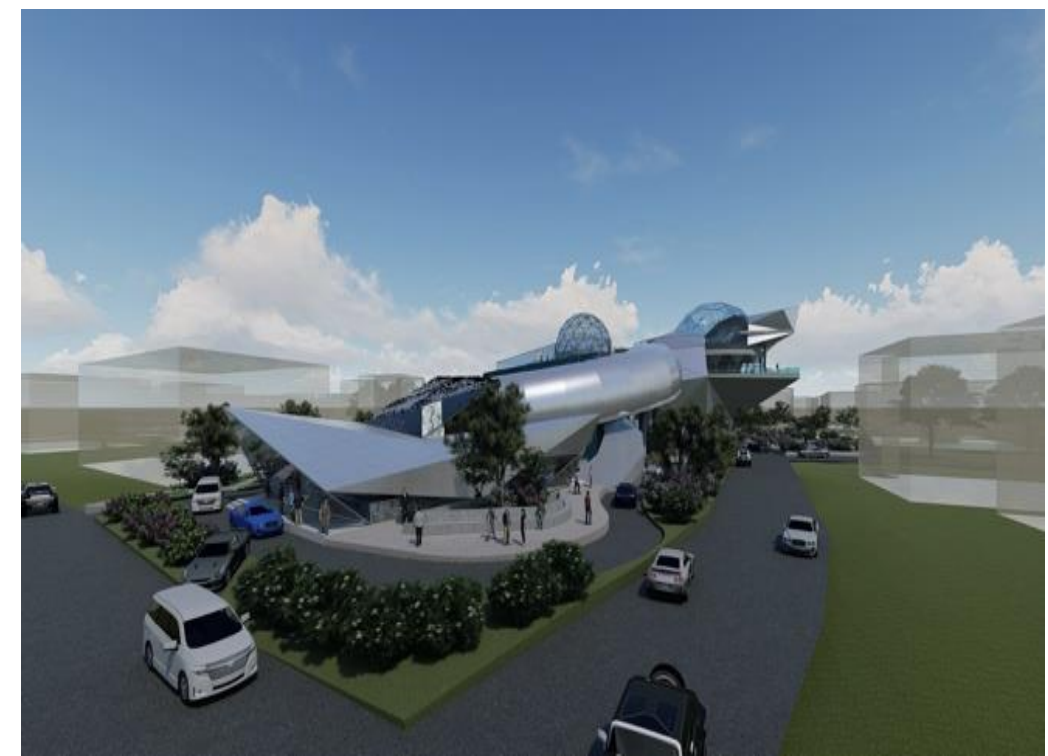

Gambar 14. Exterior Bangunan

Sumber: Penulis, 2020

\section{Zoning}

Berikut merupakan distribusi program berdasarkan zoning dan program ruang :

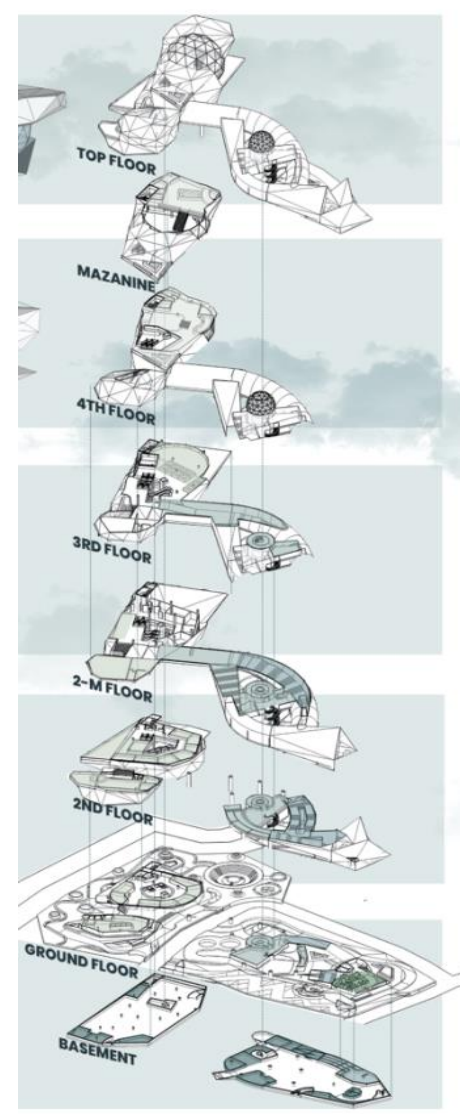

\section{ZONING}

\section{RECONNECTING}

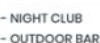

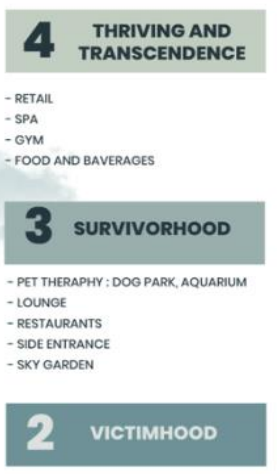

NATURE : RAIN FOREST, OCEAN, CAVE

- CUBICAL: VR CONSULTATION

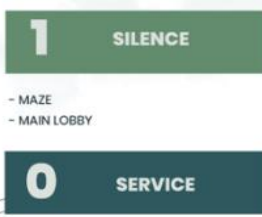

- LOADING DOCK

- RUANO ELECTRICAL : OENSET, TRAFO.

PANEI

- STP. WTP. POMPA AQUARIUM

- MUANO PENOELOLA

Gambar 15. Zoning

Sumber: Penulis, 2020 


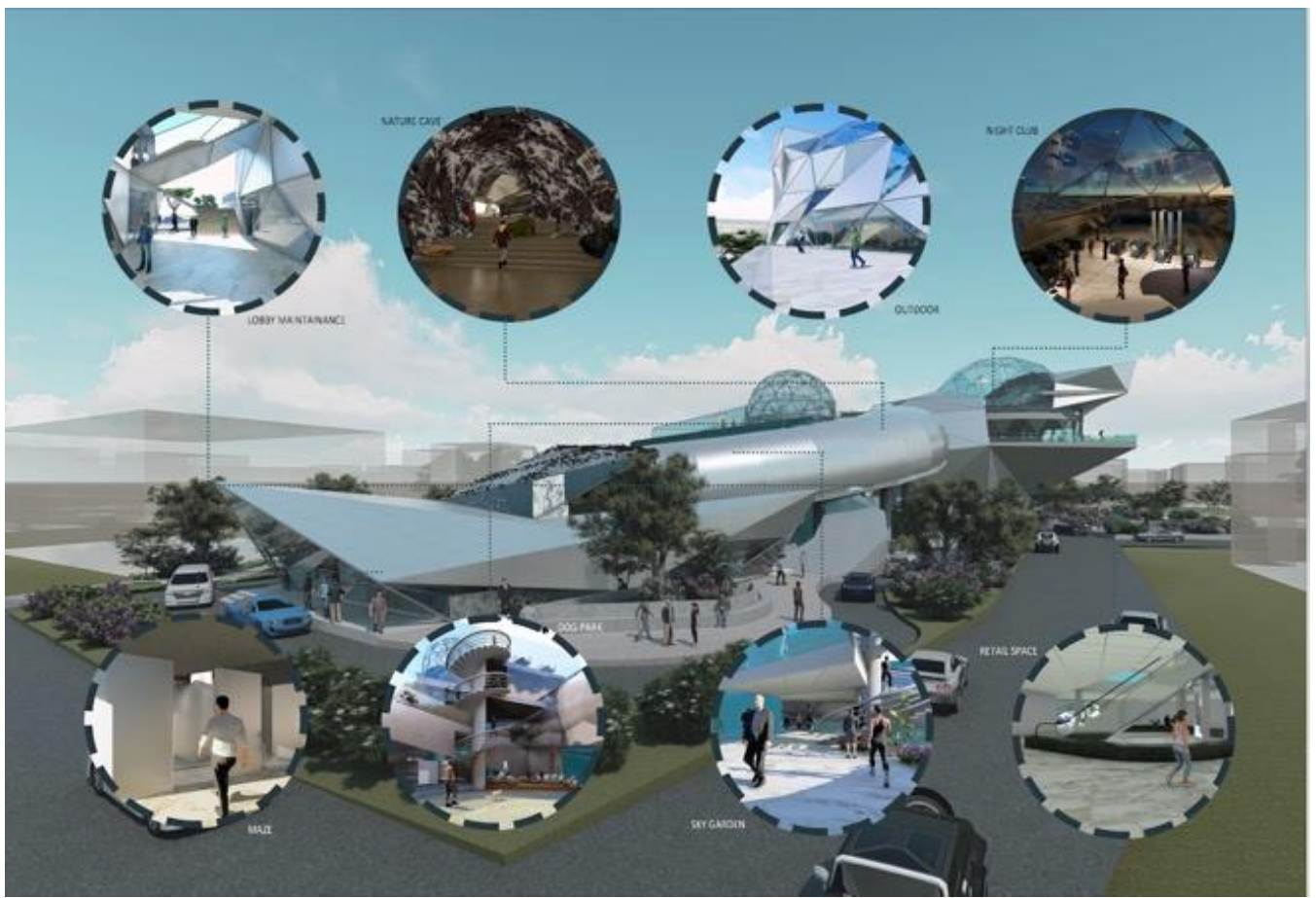

Gambar 16. Distribusi Program dalam Bangunan

Sumber: Penulis, 2020

\section{KESIMPULAN DAN SARAN}

\section{Kesimpulan}

Kesehatan mental merupakan aspek dasar dalam kehidupan manusia untuk mereka berfungsi. Arsitektur pemegang peran dalam membentuk pengalaman ruang. dalam proses pemulihan terdapat beberapa tahap untuk mencapai level kenormalan baru pada diri manusia. Dalam tahapan pemulihan arsitektur mempengaruhi dari segi bentuk, suasana ruang dan aktifitas yang tertera dalam bangunan. Program yang dibuat berdasarkan 3 tahap pemulihan berdasarkan Herman MD yang dipecah menjadi 5 tahap berkala. Penggabungan program berupa entertainment sendiri yang didistribusi dalam bangunan merupakan kegiatan relaksasi berkala yang biasa gen z lakukan.

Dapat disimpulkan bahwa efek psikologis pada manusia sangat berperan penting dalam pembentukan suasana ruang. Recovery dibuat bertahap dengan mengimplementasikan karakter dan bentuk ruang terhadap psikologis manusia itu sendiri.

\section{Saran}

Aspek psikologi mempengaruhi arsitektur dan begitupun sebaliknya. Dengan adanya hal tersebut maka bentu, fungsi, ruang mempengaruhi mental health seseorang. Pendalaman psikilogi dibutuhkan untuk penerapan dalam ruang. Arsitektur diharapkan dapat mengimbangi dan menaikan kualitas sikologi manusia dalam keseharian aktivitas mereka. Seperti yang di katakan Herman MD proses pemulihan dilakukan secara bertahap dan di lengkapi dengan fasilitas yang mendukung. Makadari itu masi dibutuhkna penyempurnaan dalam proyek ini dikarekakan keterbatasan refrensi dan teori pasti terhadap asitektur dan mental health. 


\section{REFERENSI}

Byrne, J., \&amp; Follow. Insight Into The 7 Stages A Mental Health Patient Experiences. Linkedln. $\quad$ https://www.linkedin.com/pulse/20140730204236-80639995-insightinto-the-7-stages-a-mental-health-patient-experiences/.

Herman, J. L. (2015). Trauma and Recovery: The Aftermath of Violence--From Domestic Abuse to Political Terror (1R ed.). Basic Books.

Riso, D. R., \& Hudson, R. (1999). The Wisdom of the Enneagram: The Complete Guide to Psychological and Spiritual Growth for the Nine Personality Types (Illustrated ed.). Bantam.

Roddick, C. B. M. L. (2015, August 3). Stages of Trauma Recovery: What It Means to Be a 'Survivor.' GoodTherapy.Org Therapy Blog. https://www.goodtherapy.org/blog/stagesof-trauma-recovery-what-it-means-to-be-a-survivor-0803155

WHO. (2013). Mental health. https://www.who.int/mental_health/management/info_sheet.pdf

Wardynski, D. J. (2019, November 7). What are the effects of technology on human interaction? https://www.brainspire.com/blog/what-are-the-effects-of-technologyon-human-interaction. 